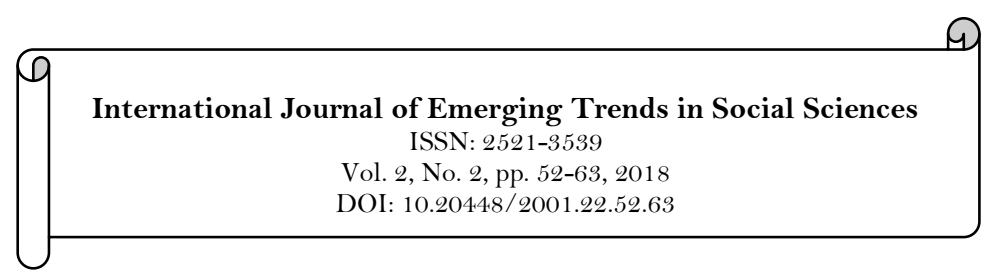

\title{
Sexual Behavior and Abuse: A Case Study of University Undergraduates in Tertiary Institutions in Imo State, Nigeria
}

\author{
Chukwuma B. Duru's \\ Anthony C. Iwu ${ }^{2}$ \\ Chinyere M. Aguocha ${ }^{3}$ \\ Uche R. Oluoha ${ }^{4}$ \\ Ijeoma N. Okedo-Alex ${ }^{5}$ \\ Emmanuel N. Ndukwu ${ }^{6}$ \\ Ernest Nwaigbo ${ }^{7}$
}

$\mathbf{8}_{1,2,4}$ Department of Community Medicine, Imo State University, Owerri, Imo State, Nigeria.

${ }^{1}$ Email: duruchukwuma16@yahoo.com

${ }^{3}$ Department of Psychiatry, Imo State University, Owerri, Imo State, Nigeria.

5 Department of Community Medicine, Federal Teaching Hospital, Abakaliki, Nigeria.

${ }^{6,7}$ Department of Community Medicine, Imo State University Teaching Hospital, Orlu Imo State, Nigeria.

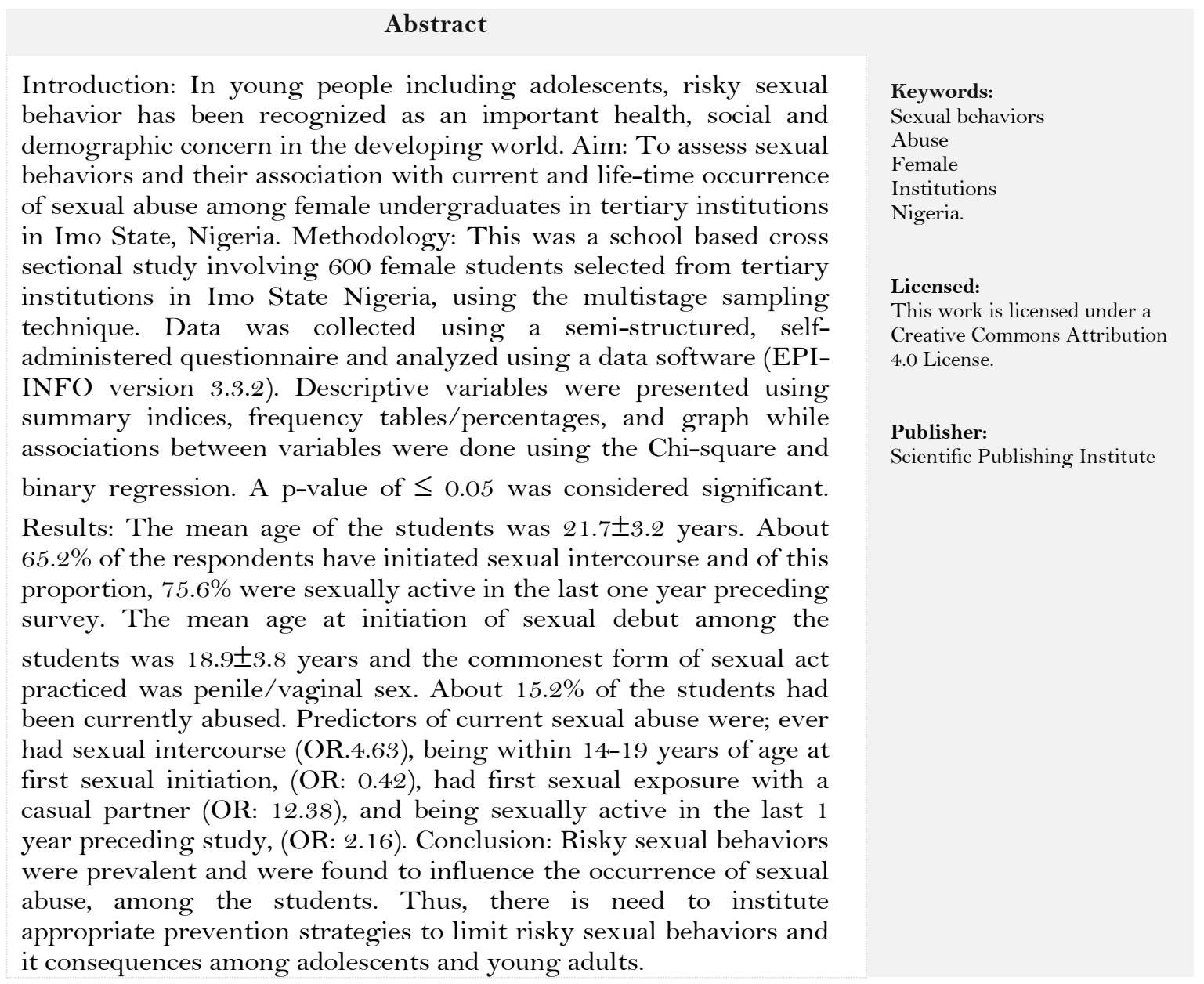

\section{Introduction}

Risky Sexual Behaviors which include, early sexual initiation/debut, unprotected sexual intercourse, multiple sexual partners, non-contraceptive use, coerced sexual intercourse, and transactional sexual intercourse can expose young adults to sexually transmitted infections (STIs) including HIV/AIDS, early un- 
intended pregnancy; early child-birth/risky childbearing from sexual escapades; suicide; and premature death from accidents, negative effects of alcoholism, drug use and violence (Chimah, Nnebue, Ilika, \& Lawoyin, 2015; Kamile, 2009; Oluwatoyin \& Oyetunde, 2014; Soboka \& Kejela, 2015).

In young people including adolescents risky sexual behavior has been recognized as an important health, social and demographic concern especially in developing world (Somba, Mbomile, Obure, \& Mahande, 2014). For many young people, university or higher institution represents a shift towards greater independence from home setting and an opportunity to form new friendships, and for several, an opportunity to experience sexual relations, and have multiple sexual partners with inconsistent condom use which makes them vulnerable to many health problems (Mulu, Yimer, \& Abera, 2014; Skinner \& Hickey, 2003). More than half of the world population is constituted of young people less than 25year of age, and majority of these populations live in developing countries In Sub-Sahara Africa, including Nigeria, youth sexual behavior has been a central issue because sexual activity is increasing in many African countries and this possess a serious risk (Kassa et al., 2016; United Nations Fund for Population Activities, 2011). University students belong to the youth age category and are exposed to risky sexual behavior as well, which can lead to transmission of STIs including HIV, unwanted pregnancies and associated consequences which may include unsafe abortions, severe illness, infertility, school drop-out, depression, career disruption and even death (Faustina, 2007; Lanre, 2009; Mulu et al., 2014; Shiferaw, Frehiwot, \& Asres, 2014; Soboka \& Kejela, 2015; Tura, Alemseged, \& Degene, 2012; World Health Organization, 2006).

Globally, one-third of the 340 million new STI cases occur annually in people under $25 y$ years of age. Each year more than one in every twenty adolescents contracts a curable STI. The United Nations estimated that nearly one of every two new HIV infections worldwide occurs among young adults between 15 and 24 years old. In Nigeria, women aged 15-44 years obtain approximately 610,000 abortions yearly at a rate of 25 abortions per 100 women with adolescents being disproportionately affected by the consequences of unsafe abortions (Duru et al., 2015b; Mulu et al., 2014; Shiferaw et al., 2014).

Sexual abuse or harassment which is on the increase among students in higher institutions of learning has been associated with various forms of risky sexual behaviors. Kullima, Kawuwa, Audu, Mariga, and Bukar (2010) reported that younger age at coitarche, history of forced coitarche, coitarche with relations and unknown persons significantly influenced subsequent risks of sexual assault among female Nigerian students. Other reviewed studies linked increased occurrence of sexual abuse with some forms of sexual behaviors like having any previous history of sexual intercourse (Adejimi, Sabeqeh, \& Adedokun, 2016; Kastbom, Sydsjo, Bladh, Priebe, \& Svedin, 2017) practicing risky sexual behaviors (Oluwatosin \& Adediwura, 2010) having a regular boyfriend (Adinew \& Hagos, 2017) alcohol and drug abuse (Adinew \& Hagos, 2017; Kastbom et al., 2017; Skinner \& Hickey, 2003) ever watched pornography (Kastbom et al., 2017; Mulu et al., 2014) prior victimization and consensual sexual activity (Mezie-Okoye \& Alamina, 2014). These studies revealed that those with risky sexual behaviors were likely to have been sexually abused and this could endanger the future of these students. Therefore this study seeks to assess the sexual behavior of these female students in tertiary institutions in Imo State and explore associations between some of the risky behaviors and occurrence of sexual abuse among the studied students with a view of finding ways to reduce this menace in the state.

\section{Methodology}

\subsection{Study Area}

Imo State is one of the 36 States of Nigeria in the South Eastern Region of the country. It has a total population of about 3.93 million people, comprising more males than females (2.03 million and 1.9 million people respectively) and an annual growth rate of about 3.0\%. The majority of the people living in the State are Igbos and the state has one the highest literacy rate in the country of over $95 \%$. Important educational institutions in the state include; Imo State University, Federal University of Technology, Eastern Palm University, Alvan Ikoku Federal College of Education, Federal Polytechnic, Nekede, Imo State Polytechnic, School of Nursing and Health Sciences, African Institute of Science and Technology, Seat of Wisdom Seminary School among others.

\subsection{Study Population and Design}

The study population comprised female undergraduate students of the selected institutions in Owerri Imo state. This was a descriptive cross sectional study.

\subsection{Inclusion and Exclusion Criteria}

Inclusion: Only female students of the selected institutions were enrolled and studied.

Exclusion criteria: All female visitors and staff of the institutions were excluded.

\subsection{Sample Size Determination}

Using the Cochran sample size formula for cross sectional studies in populations greater than 10,000 people and the proportion of sexually active students in a closely related study from Nigeria, 49.4\% (Duru et al., 2015a). 
Thus applying the formula below;

$\mathrm{n}=\mathrm{Z}^{2} \mathrm{Pq} / \mathrm{d}^{2}$ (Cochran, 1977)

Where $\mathrm{n}$ is the minimum sample size, $\mathrm{Z}=$ standard normal deviate set at $95 \%$ significance level $\approx 1.96, \mathrm{p}=$ the prevalence of sexually active students from a previous study $=61 \%, q=1-p, d=$ the degree of accuracy set at 0.05. A sample size of 600 female students were enrolled and studied.

\subsection{Sampling Technique}

The study was carried out using the multistage sampling technique.

STAGE 1: This involved the stratification of the institutions into two categories; category A: Universities and category B: Non-universities, and using simple random sampling by balloting one institution was selected from each category. Thus Imo State University Owerri was selected from Category A while Alvan IKoku Federal College of Education was selected from Category B. Three Hundred students each was studied in both institutions.

STAGE 11: This involved selection of the Faculties and Departments to be studied. This was done using proportionate simple random sampling by balloting based on population size of the selected Faculties and Departments.

STAGE 111: This involves the selection of the study participants. This was done using cluster sampling technique. The classes studied were grouped into clusters from 100-600 level. And one cluster from each class was selected using simple random sampling. All selected clusters were studied.

\subsection{Data Collection and Analysis}

Data was collected using a pretested, semi structured, self-administered questionnaire. The questionnaire contained three sections; Section A: Socio demographic characteristics of students, Section B: sexual behavior of students, and Section C: sexual abuse among students. Quantitative data collected were cleaned and validated manually, while a computer software package (EPI INFO version 3.3.2) was used for data entry and analysis. Frequencies and percentages of relevant variables were generated, bivariate analysis was conducted using Chi-square and logistic regression to test associations between variables. A p-value $<0.05$ was considered statistically significant.

\subsection{Ethical Consideration}

Ethical approval was gotten from the Department of Community Medicine, Madonna University, Nigeria and Office of the Dean of Student Affairs of both institutions. An informed consent was obtained from each respondent. The study followed the ethical principles guiding the use of human participants in research as declared in Helsinki, 1964.

\section{Results}

Table-3.1. Sociodermographic Characteristics of Respondents.

\begin{tabular}{l|l|l}
\hline \multicolumn{3}{c}{ Table-3.1. Sociodermographic Characteristics of Respondents. } \\
\hline AGE GROUP & Frequency & Percentage \\
$<20$ & 230 & \\
$21-25$ & 306 & 38.3 \\
$>26$ & 64 & 51.0 \\
Total & $\mathbf{6 0 0}$ & 10.7 \\
\hline MARITAL STATUS & & $\mathbf{1 0 0}$ \\
Single & 522 & \\
Ever married & 78 & 87.0 \\
Total & $\mathbf{6 0 0}$ & 13.0 \\
\hline FACULTY OF STUDY & & $\mathbf{1 0 0 . 0}$ \\
Humanities & 180 & \\
Education & 150 & 30.0 \\
Sciences/Engineering/Agriculture & 105 & 25.0 \\
Management & 95 & 17.5 \\
Health Sciences & 70 & 15.8 \\
Total & $\mathbf{6 0 0}$ & 11.7 \\
\hline LEVEL IN SCHOOL & & $\mathbf{1 0 0 . 0}$ \\
100 & 39 & \\
200 & 118 & 6.5 \\
300 & 246 & 19.7 \\
$>$ 400 & 197 & 41.0 \\
Total & $\mathbf{6 0 0}$ & 32.9 \\
\hline RESIDENCE IN SCHOOL & & $\mathbf{1 0 0 . 0}$ \\
\hline
\end{tabular}




\begin{tabular}{l|l|l}
\hline School hostel & 155 & 25.8 \\
Off campus & 321 & 53.5 \\
Living with family members & 124 & 20.7 \\
Total & $\mathbf{6 0 0}$ & $\mathbf{1 0 0 . 0}$ \\
\hline RELIGION & & \\
Catholic & 290 & 48.3 \\
Pentecostal & 181 & 30.2 \\
Orthodox & 122 & 20.3 \\
Islam & 7 & 1.2 \\
Total & $\mathbf{6 0 0}$ & $\mathbf{1 0 0 . 0}$ \\
\hline TRIBE & & \\
Igbo & 555 & 92.5 \\
Non-Igbo & 45 & 7.5 \\
Total & $\mathbf{6 0 0}$ & $\mathbf{1 0 0 . 0}$ \\
\hline Source: Data analysed &
\end{tabular}

Source: Data analysed.

\subsection{Socio-Demographic Characteristics of Respondents.}

The mean age of respondents was $21.7 \pm 3.2$ years with majority of them being within 25 years of age $(89.3 \%)$, and were singles $522(87 \%)$. A higher proportion of the students were in 300 level of study $246(41.0 \%)$ with more than half of them residing off campus $321(53.5 \%)$. Majority of them were of Igbo extraction $555(92.5 \%)$ and almost half of them were Catholics 290(48.3\%). Table 3.1.

Table-3.2. Sexual Behaviour of Respondents.

\begin{tabular}{|c|c|c|}
\hline VARIABLE & FREQUENCY & PERCENTAGE \\
\hline \multicolumn{3}{|l|}{ EVER HAD SEX $(n=600)$} \\
\hline Yes & 391 & 65.2 \\
\hline No & 209 & 34.8 \\
\hline TOTAL & 600 & 100.0 \\
\hline \multicolumn{3}{|l|}{ **FORMS OF SEXUAL ACT PRACTICED (n=391) } \\
\hline Penile/ Vaginal & 285 & 72.9 \\
\hline Lesbianism & 55 & 14.1 \\
\hline Rape/ Incest & 49 & 12.5 \\
\hline Anal intercourse & 45 & 11.5 \\
\hline Pornography/Internet sex & 8 & 2.0 \\
\hline \multicolumn{3}{|l|}{ AGE AT FIRST EXPOSURE $(n=391)$} \\
\hline$>20$ & 160 & 40.9 \\
\hline Total & 391 & 100 \\
\hline \multicolumn{3}{|l|}{ Mean $=18.9 \pm 3.8$, MEDIAN $=18.1$} \\
\hline \multicolumn{3}{|l|}{ PERSON HAD FIRST SEXUAL EXPOSURE WITH $(n=391)$} \\
\hline Boyfriend & 278 & 71.1 \\
\hline Colleague & 25 & 6.4 \\
\hline Teacher & 24 & 6.1 \\
\hline Causal friend & 19 & 4.9 \\
\hline My boss at work & 18 & 4.6 \\
\hline Relative/family member & 14 & 3.6 \\
\hline Man friend & 13 & 3.3 \\
\hline \multicolumn{3}{|l|}{ AGE OF PERSON WITH FIRST EXPOSURE $(n=391)$} \\
\hline Yes & 207 & 52.9 \\
\hline No & 184 & 47.1 \\
\hline Total & 391 & 100.0 \\
\hline \multicolumn{3}{|l|}{ WHO SUGGESTED USE $(n=207)$} \\
\hline $\mathrm{Me}$ & 66 & 31.9 \\
\hline My partner & 62 & 29.9 \\
\hline Both of us & 79 & 38.2 \\
\hline Total & 207 & 100.0 \\
\hline
\end{tabular}




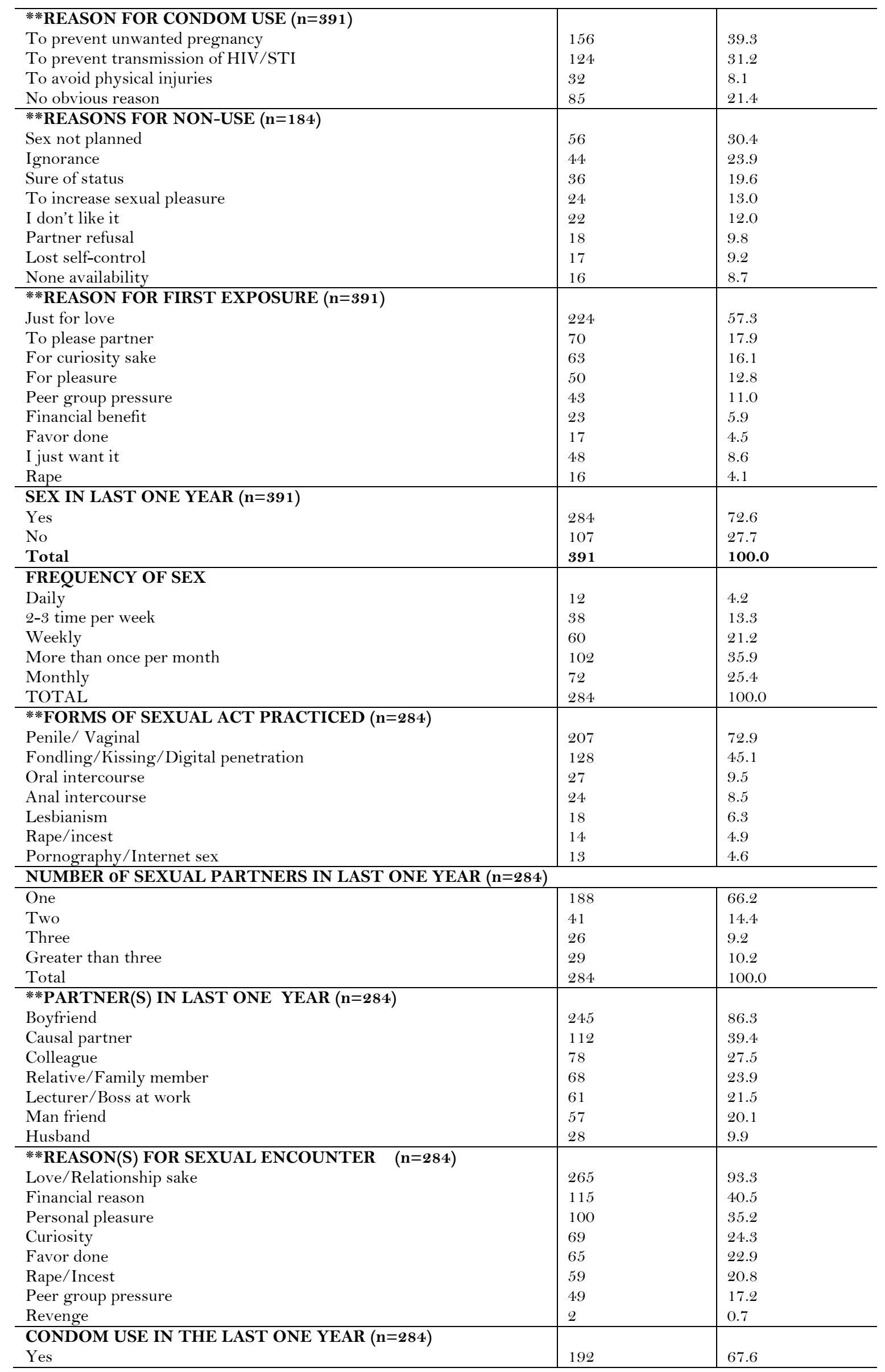




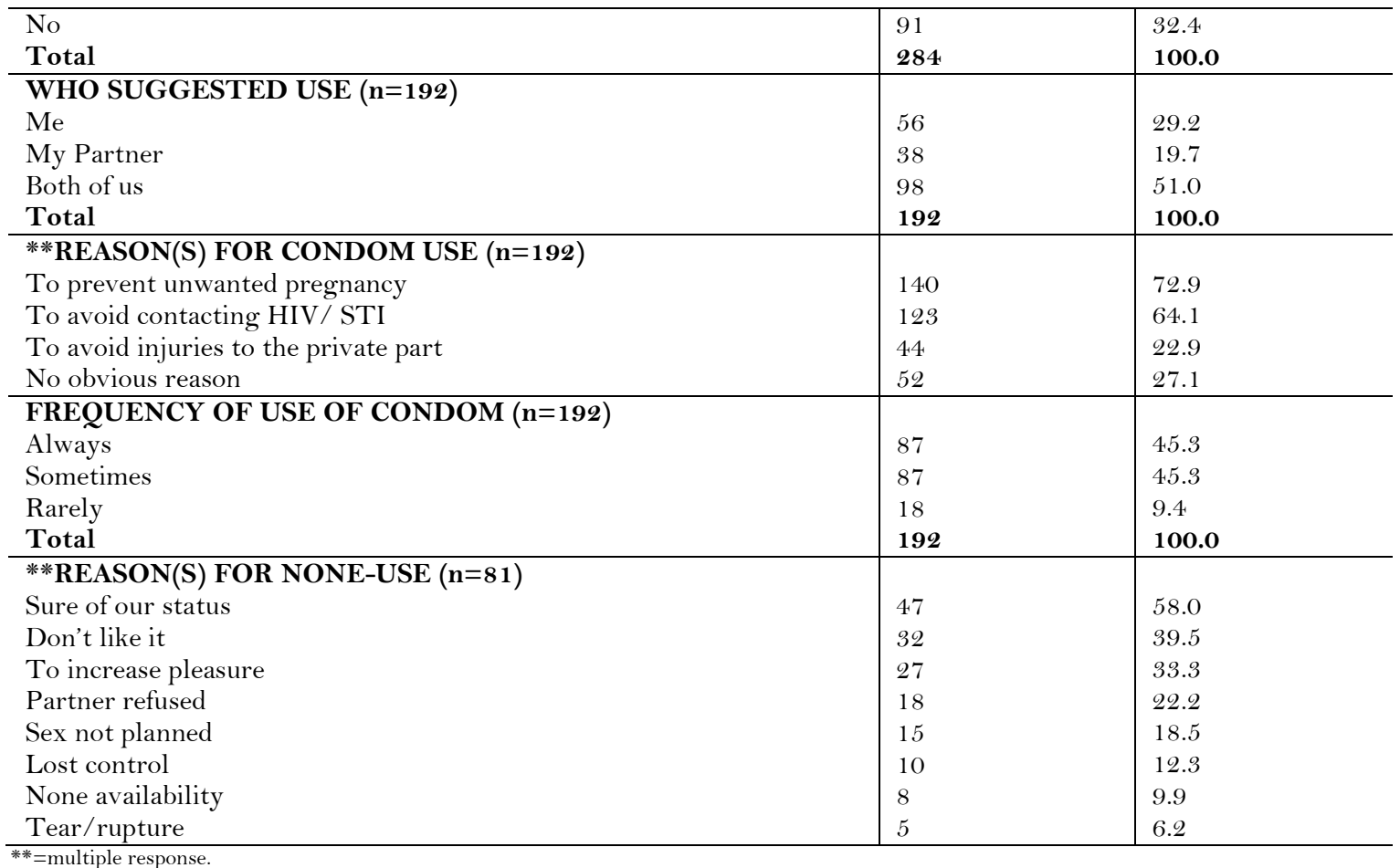

Majority of the respondents 391(65.2\%) have had prior sexual exposure with most of them having indulged in penetrative penile/vaginal sexual intercourse, $(72.9 \%)$, followed by foundling/kissing/ digital penetrative sex (49.1\%). The mean and median age of first sexual exposure were $18.9 \pm 3.8$ and 18.1 years respectively and majority of them had their first sexual exposure with their boyfriends (71.1\%). Most of their first sexual debut was performed with older persons (74.4\%) with slightly above half of them, (52.9\%), using condom in their first sexual debut, and use was mainly suggested by both partners $(38.2 \%)$. Commonest reason for condom use in first sexual debut was prevention of unwanted pregnancy (39.3\%) followed by prevention of HIV/STI transmission, (31.3\%). Common reasons for indulging in first sexual debut were; just for love $(57.3 \%)$, to please partner $(17.9 \%)$ and curiosity $(16.1 \%)$. Majority of those who have had sex before $(72.6 \%)$ also had sex in the last one year, with a higher proportion of them having sex more than once a month $(35.9 \%)$. The major forms of sexual act practiced were; penile/vaginal sex, $(72.9 \%)$, and fondling/kissing $(45.1 \%)$, and majority of them $(62.2 \%)$ had just one sexual partner in the last one year. Most of them $(86.3 \%)$ claimed that their boyfriend(s) was their main partner in the last one year though those that had casual sexual partners was sizable, $(39.4 \%)$. Common reasons for current sexual encounter given were; for love/relationship sake $(93.3 \%)$, financial reason, $(40.5 \%)$ and personal pleasure, $(32.2 \%)$. Majority $(67.6 \%)$ of women who had sex in the last I year used condoms though less than half of them, (45.3\%) used it always. Condom use was mainly suggested by both partners $(51.0 \%)$, and the commonest reason for use was to prevention unwanted pregnancy $(72.9 \%)$ while that for none use was being sure of status, (58.0\%). Table 3.2.

Table-3.3. Current occurrence of STI and treatment received among respondents.

\begin{tabular}{l|l|l}
\hline Variable & Frequency & Percentage \\
\hline HAVE YOU HAD AN STI IN THE LAST 1 YEAR (n=600) & 20.0 \\
Yes & 120 & 80.0 \\
No & 480 & $\mathbf{1 0 0 . 0}$ \\
Total & $\mathbf{6 0 0}$ & \\
\hline **SYMPTOMS OF THE STI NOTICED (n=120) & 65.8 \\
Itching in private part & 28.3 \\
Pain at the private part & 34 & 25.0 \\
Lower abdominal pain & 30 & 18.3 \\
Vaginal discharge & 22 & 10.0 \\
Fever/chills and rigors & 12 & 9.2 \\
Painful urination & 11 & 9.2 \\
Pain during intercourse & 11 & 5.0 \\
Rashes at the private part & 6 & 2.5 \\
Vaginal sores & 3 & \\
\hline RECEIVED ANY FORM OF TREATMENT(n=120) & 75.8 \\
Yes & 91 & 24.2 \\
No & 29 & $\mathbf{1 0 0 . 0}$ \\
Total & $\mathbf{1 2 0}$ & \\
\hline
\end{tabular}




\begin{tabular}{|c|c|c|}
\hline $\begin{array}{l}\text { PLACE OF TREATMENT }(\mathbf{n}=\mathbf{9 1}) \\
\text { Hospital } \\
\text { Chemist/Pharmacy/Private laboratory } \\
\text { Home } \\
\text { Herbal home } \\
\text { Total }\end{array}$ & $\begin{array}{l}42 \\
38 \\
10 \\
1 \\
\mathbf{9 1}\end{array}$ & $\begin{array}{l}46.2 \\
41.8 \\
11.0 \\
1.0 \\
\mathbf{1 0 0 . 0} \\
\end{array}$ \\
\hline $\begin{array}{l}\text { DURATION OF TREATMENT RECEIVED }(\mathbf{n = 9 1}) \\
\text { One week } \\
\text { Two weeks } \\
\text { Three weeks } \\
\text { One month } \\
\text { More than one month } \\
\text { Total }\end{array}$ & $\begin{array}{l}25 \\
40 \\
15 \\
6 \\
5 \\
\mathbf{9 1}\end{array}$ & $\begin{array}{l}27.5 \\
44.0 \\
16.5 \\
6.6 \\
5.4 \\
100.0\end{array}$ \\
\hline $\begin{array}{l}\text { WHO TREATED YOU }(\mathbf{n}=\mathbf{9 1}) \\
\text { Medical Doctor } \\
\text { Laboratory Scientist } \\
\text { Chemist/pharmacist } \\
\text { Self } \\
\text { Herbalist } \\
\text { Total }\end{array}$ & $\begin{array}{l}50 \\
17 \\
13 \\
10 \\
1 \\
91\end{array}$ & $\begin{array}{l}54.9 \\
18.7 \\
14.9 \\
11.0 \\
1.1 \\
100.0\end{array}$ \\
\hline $\begin{array}{l}\text { DIAGNOSIS MADE }(\mathbf{n}=\mathbf{9 1}) \\
\text { Bacteria vaginosis } \\
\text { Gonorrhea } \\
\text { Syphilis } \\
\text { Chlamydia } \\
\text { Total }\end{array}$ & $\begin{array}{l}36 \\
22 \\
22 \\
11 \\
\mathbf{9 1}\end{array}$ & $\begin{array}{l}39.5 \\
24.2 \\
24.2 \\
12.1 \\
\mathbf{1 0 0 . 0}\end{array}$ \\
\hline
\end{tabular}

About one-fifth of the women (20.0\%), had STI in the last 1 year and the commonest STI diagnosed was bacteria vaginosis, (39.5\%). The common presenting symptoms were; genital itching (55.8\%), genital pain (28.3\%) and lower abdominal pain (25.0\%). Majority of those that had STI, (75.8\%) received treatments and common places of treatment were in the hospitals (46.2\%), and Chemist/ Pharmacy/Private laboratory, $(41.8 \%)$. More than half of the women, $(54.9 \%)$ claimed to have been treated by a Medical doctor and most of the treatments, $(71.5 \%)$, lasted for at least 2 weeks. Table 3.3.

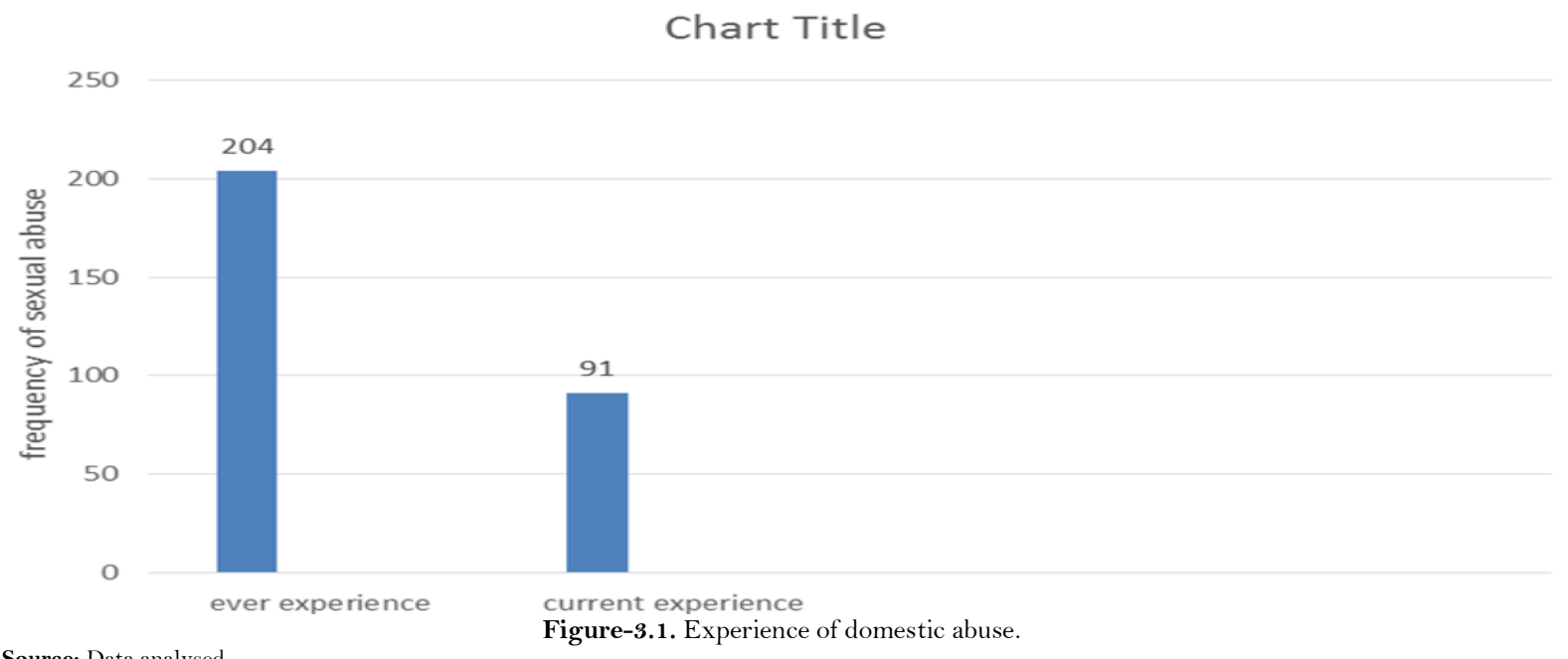

Source: Data analysed.

The prevalence of ever experience of sexual abuse and current experience of sexual abuse among the female students were; $204(34.0 \%)$ and $91(15.2 \%)$ respectively. Figure 3.1. 
Table-3.4. Association between Some Selected Sexual Behaviour of Respondents and Ever Experience of Sexual Abuse.

\begin{tabular}{|c|c|c|c|c|c|}
\hline \multirow{2}{*}{ VARIABLE } & \multicolumn{3}{|c|}{ Ever experienced sexual abuse } & \multirow{2}{*}{$\begin{array}{l}\text { Statistics }\left(\mathrm{X}^{2}\right) / \mathrm{p}- \\
\text { value }\end{array}$} & \multirow[t]{2}{*}{ OR: $(95 \% \mathrm{CI})$} \\
\hline & YES (\%) & NO (\%) & TOTAL (\%) & & \\
\hline \multicolumn{6}{|c|}{ HAVE YOU HAD SEXUAL INTERCOURSE BEFORE } \\
\hline Yes & $180(46.0)$ & $211(54.0)$ & $391(100)$ & 72.461 & $6.57 *(4.11-10.51)$ \\
\hline No & $24(11.5)$ & $185(88.5)$ & $209(100)$ & $\mathrm{p}=\mathbf{0}^{*}$ & 1.00 \\
\hline TOTAL & $204(34.0)$ & $396(66.0)$ & $600(100)$ & & \\
\hline \multicolumn{6}{|c|}{ AGE AT FIRST EXPOSURE $(n=391)$} \\
\hline$<10$ & $2(40.0)$ & $3(60.0)$ & $5(100)$ & & 1.00 \\
\hline $10-13$ & $12(46.2)$ & $14(53.8)$ & $26(100)$ & 0.264 & $1.28(0.18-9.02)$ \\
\hline $14-19$ & $97(48.5)$ & $103(51.5)$ & $200(100)$ & $\mathrm{p}=0.607$ & $1.41(0.23-8.64)$ \\
\hline$>20$ & $69(43.1)$ & $91(56.9)$ & $160(100)$ & & $1.14(0.185-6.99)$ \\
\hline TOTAL & $180(46.0)$ & $211(54.0)$ & $391(100)$ & & \\
\hline \multicolumn{6}{|c|}{ CONTACT ON FIRST EXPOSURE $(n=391)$} \\
\hline & & & & 4.307 & $3.18^{*}(1.88-5.37)$ \\
\hline Boyfriend & $141(50.7)$ & $137(49.2)$ & $278(100)$ & $\mathrm{p}=0.038^{*}$ & $16.47 *(4.40-61.62)$ \\
\hline Casual friend & $16(84.2)$ & $3(15.8)$ & $19(100)$ & & 1.00 \\
\hline Others ${ }^{1}$ & $23(24.4)$ & $71(75.5)$ & $94(100)$ & & \\
\hline TOTAL & $180(46.0)$ & $211(54.0)$ & $391(100)$ & & \\
\hline \multicolumn{6}{|c|}{ HAD SEXUAL INTERCOURSE IN THE LAST ONE YEAR } \\
\hline Yes & $125(44.0)$ & $159(56.0)$ & $284(100)$ & 50.430 & $3.73 *(2.58-5.42)$ \\
\hline No & $55(17.4)$ & $261(82.6)$ & $316(100)$ & $\mathrm{p}=\mathbf{0}^{*}$ & 1.00 \\
\hline TOTAL & $180(30.0)$ & $420(70.0)$ & $600(100)$ & & \\
\hline
\end{tabular}

Sexual behavior of students that were found to be associated with life-time experience of sexual abuse were; ever had sexual intercourse, $\left(\mathrm{X}^{2}=72.461, \mathrm{p}=0\right)$, persons they had first exposure with, $\left(\mathrm{X}^{2}=4.307, \mathrm{p}=0.038\right)$, and current sexual exposure in the last one year preceding survey, $\left(\mathrm{X}^{2}=50.430, \mathrm{p}=0\right)$. Female students who had sexual intercourse before,(OR:6.57;4.11-10.51), had first sexual exposure with a casual partner, (OR:16.47;4.40-61.62) and had sexual intercourse in the last I year preceding survey, (OR:3.73;2.58-5.42) were more likely to had experienced any form of life-time sexual abuse than their counterparts with better sexual behavior Table 3.5.

Table-3.5. Association between Selected Sexual Behaviour of Respondents and Experience of Current Sexual Abuse.

\begin{tabular}{|c|c|c|c|c|c|}
\hline \multirow[t]{2}{*}{ Variable } & \multicolumn{3}{|c|}{ Current Experience of sexual abuse } & \multirow{2}{*}{$\begin{array}{l}\text { Statistics }\left(\mathbf{X}^{2}\right) / \\
\text { p-value }\end{array}$} & \multirow[t]{2}{*}{ OR: $(95 \% \mathrm{CI})$} \\
\hline & YES (\%) & NO (\%) & TOTAL (\%) & & \\
\hline \multicolumn{6}{|c|}{ HAVE YOU HAD SEXUAL INTERCOURSE BEFORE } \\
\hline Yes & $80(20.5)$ & $311(79.5)$ & $391(100)$ & 24.447 & $4.63 *(2.41-8.91)$ \\
\hline No & $11(5.3)$ & $198(94.7)$ & $209(100)$ & $\mathrm{p}<0.0001^{*}$ & 1.00 \\
\hline TOTAL & $91(15.2)$ & $509(84.8)$ & $600(100)$ & & \\
\hline \multicolumn{6}{|c|}{ AGE AT FIRST EXPOSURE } \\
\hline$<13$ & $7(22.5)$ & $24(77.5)$ & $31(100)$ & 5.468 & 1.00 \\
\hline $14-19$ & $22(11.0)$ & $178(89.0))$ & $200(100)$ & $\mathrm{p}=0.019$ & $0.42 *(0.16-0.99)$ \\
\hline$>20$ & $51(31.9)$ & $109(68.1)$ & $160(100)^{\prime}$ & & $1.60(0.65-3.97)$ \\
\hline TOTAL & $80(20.5)$ & $311(79.5)$ & $391(100)$ & & \\
\hline \multicolumn{6}{|c|}{ CONTACT ON FIRST EXPOSURE $n=391$} \\
\hline Boyfriend & $53(19.1)$ & $225(80.9)$ & $278(100)$ & 4.018 & $1.35(0.70-2.56)$ \\
\hline Casual friend & $14(68.4)^{\prime}$ & $5(31.5)$ & $19(100)$ & $\mathrm{p}=0.045^{*}$ & $12.38 *(4.04-38.01)$ \\
\hline Others ${ }^{1}$ & $13(14.8)$ & $81(85.2)$ & $94(100)$ & & 1.00 \\
\hline Total & $80(20.5)$ & $311(79.5)$ & $391(100)$ & & \\
\hline \multicolumn{6}{|c|}{ HAD SEXUAL INTERCOURSE IN THE LAST ONE YEAR } \\
\hline Yes & $51(18.0)$ & $233(82.0)$ & $284(100)$ & 9.885 & 2.16 * $(1.33-3.52)$ \\
\hline No & $29(9.2)$ & $287(90.3)$ & $316(100)$ & $\mathrm{p}=0.002^{*}$ & 1.00 \\
\hline TOTAL & $80(13.3)$ & $520(86.7)$ & $600(100)$ & & \\
\hline
\end{tabular}

Ever had an exposure to sexual intercourse significantly influenced current experience of sexual abuse, $\left(\mathrm{X}^{2}=24.447, \mathrm{p}<0.0001\right)$, with those who have had sex before in their lifetime being about 5 times more likely to have been currently abused than their counterparts who have not had any form of sexual exposure, (OR:4.63;2.14-8.91). Also age at first sexual exposure, $\left(\mathrm{X}^{2}=5.468, \mathrm{p}=0.019\right)$, contact on first exposure, $\left(\mathrm{X}^{2}=4.018, \mathrm{p}=0.045\right)$, and had sexual intercourse in the last one year, $\left(\mathrm{X}^{2}=9.885, \mathrm{p}=0.002\right)$, all influenced current experience of sexual abuse. Those who had first sexual exposure within the ages of 14-19 years of age, (OR: 0.42; 0.16-0.99) being the least likely to have been currently abused while those who had first sexual 
exposure with a casual partner, (OR: 12.38; 4.04-38.01) and those who have had sex in the last one year preceding the survey, (OR: 2.16; 1.33-3.52) were more likely to have been currently abused than their other counterparts. Table 3.5.

\section{Discussion}

The mean age of the respondents was $21.7 \pm 3.2$ years. This was comparable to other mean ages reported in similar studies among students in higher institutions (Adinew \& Hagos, 2017; Akintayo, Akin-Akintayo, Adanikin, \& Ade-Ojo, 2015; Duru et al., 2015a; Hogue, 2011; Kamile, 2009; Mavhand-Madzusi \& Asgedom, 2015). This fall within age range of youths and young adults which is the likely mean age of most university students. About two-third of the students (65.2\%) reported ever having a sexual experience in their life-time with $72.6 \%$ of them being sexually active in the last one year proceeding the study. This finding was comparable to figures reported from similar studies, from the state (Duru et al., 2015a) South Western part of the country (Akintayo et al., 2015) South Africa and Ethiopia respectively (Hogue, 2011; Mavhand-Madzusi \& Asgedom, 2015). It was higher than figures reported in other studies from Ethiopia (Fantahum, Wahdey, \& Gebrekirstos, 2015; Kassa et al., 2016; Soboka \& Kejela, 2015; Toferra, Erena, \& Kebede, 2015) but lower than that reported from Sweden (Kastbom et al., 2017) Swaziland (Taruvinga, 2014) and Niger Delta region of the country (Akanbi, Enyindah, \& Babatunde, 2008). These variations could be due to the type of students studied in the different higher institutions, the level of knowledge of the students towards reproductive health issues, cultural and religious beliefs which could influence initiation of sexual activity among adolescents. The high level of current sexual activity reported in this study is worrisome as this could lead to a lot of reproductive health problems among the students.

The mean age at first sexual initiation reported by the students was $18.9 \pm 3.8$ years. This figure was slightly higher than the country's national average of 17.6 years (National Population Commission, Nigeria). It was also higher than figures reported from similar studies among undergraduates in Ethiopia (Adinew \& Hagos, 2017; Kassa et al., 2016; Soboka \& Kejela, 2015). Nevertheless it was comparable findings in other of the reviewed studies (Akintayo et al., 2015; Hogue, 2011; Mulu et al., 2014; Toferra et al., 2015). This high age of initiation of sexual activity found in this study will have a lot of benefits to these women in that they may be better informed to take care of their reproductive health challenges. Generally in the country, there is an increasing rate of sexual activity among adolescent girls and youths with decreasing age of initiation of first sexual debut (Duru et al., 2015b; Duru, Ubajaka, Nnebue, Ifeadike, \& Okoro, 2010). Perhaps their educational level, religion beliefs, level of awareness about reproductive health issues, family and cultural factors might have played some significant role in this high age of initiation of first sexual debut.

Majority of the respondents had their first sexual debut with their boyfriend, most of which were older than them and their common reasons were; just for love and to please their partner. Boyfriends have been noted in several studies as the main perpetrators in initiating first sexual debut among young women (Duru et al., 2015b; Fantahum et al., 2015; Kullima et al., 2010; Soboka \& Kejela, 2015). The reasons given for carrying out this action were similar to what was reported from several other studies (Duru et al., 2015b; Fantahum et al., 2015; Kassa et al., 2016; Soboka \& Kejela, 2015; Toferra et al., 2015). This is worrisome in that the feeling alone that their partner was a friend could give a sense of false security thereby leading to likely practice of risky sexual behaviors that could endanger their health. The commonest form of sexual act practiced both in the lifetime and currently was penile/vaginal sex. Other studies in Nigeria also reported a similar pattern (Duru et al., 2015b; Duru et al., 2010). Heterosexual activities have been noted to be common among Africans which was reflected in this study. A sizeable proportion of the respondents (33.8\%) reported having more than two sexual partners in the last 1 year proceeding study and their commonest partner in the last 1 year was their boyfriend followed by causal partner, colleague and relative. In most studies reviewed, a sizeable proportion of female adolescents and young adult reported having sexual relationship with multiple sexual partners even though this occurred in varying proportions (Adinew \& Hagos, 2017; Akintayo et al., 2015; Duru et al., 2015b; Duru et al., 2010; Fantahum et al., 2015; Hogue, 2011; Kamile, 2009; Kassa et al., 2016; Mavhand-Madzusi \& Asgedom, 2015; Toferra et al., 2015). Having multiple partners is a form of risky behavior and could predispose these young adults to STIs/HIV, unwanted pregnancy and consequences which are on the rise globally. People in this age bracket are young and energetic and want to experiment most issues at times at the detriment of their lives.

Current condom use was higher than use during initial debut, (OR: 1.88; 236-2.57), but the level of consistent use was low among the students. This pattern has been reported in other studies among young people (Akintayo et al., 2015; Duru et al., 2015b; Duru et al., 2010; Fantahum et al., 2015; Hogue, 2011; Mavhand-Madzusi \& Asgedom, 2015; Toferra et al., 2015). This higher use of condom in current sexual debut may likely be due to increase in awareness of the importance of its use in the prevention of STI/HIV and unwanted pregnancy which were the common reasons mentioned for using condoms in their debuts. This finding was not surprising because condom is one of the most publicized modes of contraception especially in the mass media and other forms of health education including the social media channels.

About $20 \%$ of the students reported having contracted STIs in the last one year preceding the study and the common symptoms reported were; itching of private part, pain at the private part and lower abdominal 
pain with more than half of the students not visiting any health facility for proper treatment. This reported prevalence of STI was comparable to $16.6 \%$ and $18 \%$ reported in studies from Ethiopia (Fantahum et al., 2015) and South Africa (Hogue, 2011) respectively but lower than figures reported from two other studies in Nigeria (Chimah et al., 2015; Duru et al., 2015b). The pattern of the symptomatic presentation were similar to that reported in two of the reviewed studies (Chimah et al., 2015; Fantahum et al., 2015). Chimah et al. (2015) reported that majority of the students sort care from chemist/patient medicine store which was in contrast with our finding which revealed that most of the students sort care from the hospital. This could be because our respondents were students in tertiary institution when compared the study which was carried out among secondary students and so they could be better aware and financially empowered to asses hospital care. This high prevalence reported STI supports the poor use of condom found in this study which might have aided the transmission of these STIs.

The study revealed an association between current and life-time sexual abuse with some risky sexual behaviors. The predicators were; having ever had sexual intercourse, having a casual contact at first exposure, having sexual intercourse in the last one year proceeding study. Having first sexual debut at age group 14-19 years was a predictor for current sexual abuse only. Several studies have associated one form of risky sexual behavior or the other with the occurrence of sexual abuse or harassment. Kullima et al. (2010) reported that younger age at coitarche, history of forced coitarche, coitarche with relations and unknown persons significantly influenced subsequent risks of sexual assault. Kastbom et al. (2017) reported from Sweden that those who have had sexual debut were more likely to have been sexually abused in their life time when compared to those that had not initiated sex, this was still the same report in a Nigerian study among undergraduates (Adejimi et al., 2016). Another study from South Western Nigeria found a significant association between having been abused and risky sexual behavior (Oluwatosin \& Adediwura, 2010) while a closely related study from the South-South part of the country reported a significant association between sexual violence and consensual sexual activity and prior victimization (Mezie-Okoye \& Alamina, 2014). Also a meta-analysis carried out on studies comparing the relationship between sexual abuse and risky sexual behaviors among adolescent boys in North America revealed that of the three outcomes considered (unprotected sexual intercourse, multiple sexual partners, and pregnancy involvement), sexually abused boys were significantly more likely than non-abused boys to report all three risky sexual behaviors (Homma, Wang, Saewye, \& Kishor, 2012). This finding is not unexpected because those exposed to sexual activities and risk sexual behaviors are likely to be exposed to conditions that can lead to sexual abuse. This can worsen the consequences of risky sexual behaviors thereby leading to increased morbidity and mortality among this special group of individuals.

\section{Conclusion}

The study reported some prevalent forms of risky sexual behaviors among the students with high level of reported occurrence of STIs in the last 1 year proceeding the study. Also some of these risky behaviors were associated with current and life-time occurrence of sexual abuse among the students. There is need to improve the sexual health of adolescent and young adults by raising awareness about risky sexual behaviors and sexual abuse, improve sexual health promotion activities among students in tertiary institutions in Nigeria, strengthen risky sexual behaviors and sexual abuse prevention initiatives and provide well equipped youth friendly reproductive health centers especially in our institutions of higher learning to tackle sexual problems related to the adolescent and young adults.

\section{Acknowledgement}

We want to acknowledge the participants and the students who helped us to collect data used for the study.

\section{References}

Adejimi, A. A., Sabeqeh, O. A., \& Adedokun, O. P. (2016). Experiences and disclosures of sexual assault among Nigerian undergraduates in a tertiary. Gender and Violence, 3(4), 208-215. Available at: https://doi/10.1089/vio.2015.0035.

Adinew, Y. M., \& Hagos, M. A. (2017). Sexual violence against female university students in Ethiopia. BMC International Health and Human Rights, 17, 19. Available at: 10.1186/s 12914-017-0127-1.

Akanbi, C. I., Enyindah, C. E., \& Babatunde, S. (2008). Emergency contraception, knowledge and perception among female Undergraduates in the Niger Delta of Nigeria. Ghana Medical Journal, 42(2), 68-70.

Akintayo, A. A., Akin-Akintayo, O. O., Adanikin, A. I., \& Ade-Ojo, I. P. (2015). Sexual and contraceptive practices among female undergraduates in a Nigerian Tertiary Institution. Ethiopian Journal of Health Sciences, 25(3), 209-216. Available at: http://dx.doi.org/10.4314/ejhs.v25:3.3.

Chimah, U. C., Nnebue, C. C., Ilika, A. L., \& Lawoyin, T. O. (2015). Sexual behavioral pattern, consequences and adopted solutions among senior secondary schools students in a Military barracks in Nigeria. International Journal of Adolescent Medicine and Health, 1-8. Available at: 10.1515/ijamh-2015-0012.

Cochran, W. (1977). Sampling techniques (3rd ed.). New York: John Wiley and Sons. 
Duru, C. B., Iwu, A. C., Diwe, K. C., Uwakwe, K. A., Merenu, I. A., Emerole, C. A., \& Oluoha, U. R. (2015a). Sexual behavior, contraceptive knowledge and use among female undergraduates in Tertiary Institutions in Imo State, Nigeria. American Journal of Medical Sciences and Medicine, 3(5), 61-66. Available at: 10.12691/ajmsm-3-5-1.

Duru, C. B., Nnebue, C. C., Uwakwe, K. A., Obi-Okaro, A. C. N., Diwe, K. C., Chineke, H. N., \& Abejega, C. (2015b). Sexual behaviours and contraceptive use among secondary school adolescents in a rural town in Rivers State, SouthSouth, Nigeria. Nigerian Journal of Medicine, 24(1), 17-27.

Duru, C. B., Ubajaka, C., Nnebue, C. C., Ifeadike, C. O., \& Okoro, O. P. (2010). Sexual behavior and practices among secondary school adolescents in Anambra State Nigeria. AFRMEDIC Journal, 1(2), 22-27.

Fantahum, A., Wahdey, S., \& Gebrekirstos, K. (2015). Risky sexual behaviors and predisposing factors among Mekelle University College of Business and Economic Students, Mekelle, Tigray, Ethiopia, 2013: cross sexual study. American Journal of Advanced Drug Delivery, 3(1), 052-058.

Faustina, O. (2007). Knowledge and practices of reproductive health issues among second cycle institutions in the Greater Accra Metropolitan Area (GAMA). Ghana Family Planning Perspectives, 23, 199-2 10.

Hogue, M. E. (2011). Reported risky sexual practices amongst female undergraduate students in Kwazulu-Natal, South Africa. African Journal of Primary Health Care $\mathcal{E}^{2}$ Family Medicine, 3(1), 281-287. Available at: http://dx.doi.org/10.4102/phcfm.v3i/1.281.

Homma, M. S. Y., Wang, N., Saewye, E., \& Kishor, N. (2012). The relationship between sexual abuse and risky sexual behavior among adolescent boys: A meta-analysis. Journal of Adolescent Health, 51(1), 18-24. Available at: http://dx.doi.org/10.1016/j.jadohealth.2011.12.032.

Kamile, K. (2009). Urkish University students' beliefs in sexual myths. Sex Disable, 27, 49-59.

Kassa, G. M., Degu, G., Yitayew, M., Misganaw, W., Muche, M., Demelash, T., \& Ayehu, M. (2016). Risky sexual behaviors and associated factors among Jiga High school and preparatory school students, Amhara Region, Ethiopia. International Scholarly Research Notes, ID4315729. Available at: http://dx.doi.org/10.1155/2016/4315729.

Kastbom, A. A., Sydsjo, G., Bladh, M., Priebe, G., \& Svedin, C. G. (2017). Differences in sexual behavior, health, and history of child abuse among students who had and had not engaged in sexual activity by the age of 18 years: A cross-sectional study. Adolescent Health, Medicine and Therapeutics, 7, 1-11. Available at: http://dx.doi.org/10.2 147/AMMT.S95493.

Kullima, A. A., Kawuwa, M. B., Audu, B. M., Mariga, A. G., \& Bukar, M. (2010). Sexual assault against female Nigeria students. African Journal of Reproductive Health, 14(3), 189-193.

Lanre, O. O. (2009). Sexual behavior of university students in South West Nigeria. Egypt Acad. J. Biology. Sci., 1(1), 85-93.

Mavhand-Madzusi, A. H., \& Asgedom, T. (2015). The prevalence of risky sexual behaviors amongst undergraduate students in Jigjiga University Ethiopia. Health SA. Gesondheld, 21, 179-1186. Available at: http://dx.doi.org /10.1016/j.hsag.2015.11.002.

Mezie-Okoye, M. M. M., \& Alamina, F. F. (2014). Sexual violence among female undergraduates in a Tertiary Institution in Port Harcourt: Prevalence pattern, determinants and health consequences. African Journal of Reproductive Health, 18(4), 79-85.

Mulu, W., Yimer, M., \& Abera, B. (2014). Sexual behavior and associated factors among students at Bahir Dar University: A cross sectional study. Reproductive Health, 18, 84. Available at: 10.1186/1742-4755-11-84.

Oluwatosin, S. A., \& Adediwura, A. A. (2010). Undergraduate history of sexual abuse, parenting style and sexual risk behavior in Southwestern Nigeria. African Research Review, 4(2), 139-155.

Oluwatoyin, F. E., \& Oyetunde, M. O. (2014). Risky sexual behavior among secondary school adolescents in Ibadan North Local Government Area, Nigeria. JNHS, 3, 34-44.

Shiferaw, K., Frehiwot, G., \& Asres, G. (2014). Assessment of adolescent communication on sexual and reproductive health matters with parents and associated factors among secondary and preparatory schools in Debremarkos town, North West Ethiopia. Reproductive Heath, 11, 1.

Skinner, S. R., \& Hickey, M. (2003). Current priorities for adolescent sexual and reproductive health in Australia. Medical Journal of Australia, 179, 158-161.

Soboka, B., \& Kejela, G. (2015). Assessment of risky sexual behaviors among Arba Minch university students, Arba Minch Town, Snupr Ethiopian. Journal Child Adolescent Behaviour, 3(2), 189. Available at: 10.4172/2375-4494.1000189.

Somba, M. J., Mbomile, M., Obure, J., \& Mahande, M. J. (2014). Sexual behavior, contraceptive knowledge and use among female undergraduate students of Muhimbili and Dares Salaam Universities, Tanzania: A cross-sectional study. BMC Women's Health, 14, 94.

Taruvinga, M. (2014). An assessment of sexual practices among urban high school students in Swaziland. Mediterranean Journal of Social Studies, 5(8), 402-405. Available at: 10.5901/mjss.2014.v5n8p402.

Toferra, T. B., Erena, A. N., \& Kebede, A. (2015). Prevalence of premarital sexual practice and associated factors among undergraduate Health Science students of Madawalabu University, Bale Goba, South East Ethiopia: Institution based cross-sectional study. Pan African Medical Journal, 20, 109. Available at: 10.1 1604/pamj.2015.20,.209.4525.

Tura, G., Alemseged, F., \& Degene, S. (2012). Risky sexual behavior and predisposing factors among students of Jimma University. Ethiopian Journal of Health Sciences, 22(3), 170-180.

United Nations Fund for Population Activities. (2011). The state of world population, people and possibilities in a world of 7 billion. New York. Retrieved from www.unfpa.org. [Accessed 26th September 2017].

World Health Organization. (2006). Investing in our future: A frame work for accelerating action for the sexual and reproductive health of the young people. Geneva Switzerland: WHO. 


\section{Bibliography}

Ambaw, F., Mossie, A. \& Gobena, T. (2010). Sexual practices and their development pattern among Jimma University students. Ethiop Journal Health Sciences, 20(1):159-167.

Joint United Nations Programme on HIV and AIDS/World Health Organization, (2006). AIDS Epidemic update, Geneva, Switzerland.

National Population Commission (NPC) Nigeria and ICF Macro, (2014). National demographic and health survey 2013. Abuja, Nigeria: National Population Commission and ICF Macro. 